\title{
The pro-apoptotic effect of a Terpene-rich Annona cherimola leaf extract on leukemic cell lines
}

\author{
Carl Ammoury ${ }^{1 \dagger}$, Maria Younes ${ }^{1 \dagger}$, Marianne El Khoury ${ }^{1}$, Mohammad H. Hodroj ${ }^{1}$, Tony Haykal ${ }^{1}$, Peter Nasr ${ }^{1}$, \\ Marilyne Sily ${ }^{1}$, Robin I. Taleb ${ }^{1}$, Rita Sarkis ${ }^{1,2}$, Rana Khalife ${ }^{3}$ and Sandra Rizk ${ }^{1 *}$ (D)
}

\begin{abstract}
Background: The edible fruit Annona cherimola has previously shown many nutritional and medicinal properties. The current study evaluates the anti-cancer and anti-proliferative properties of Annona cherimola ethanolic leaf extract (AELE) on Acute Myeloid Leukemia (AML) cell lines cultured in vitro (Monomac-1 and KG-1).

Methods: The anti-proliferative effect of A. cherimola ethanolic leaf extract was evaluated via cell viability assay. Its pro-apoptotic effect was assessed through Cell Death ELISA and dual Annexin V/PI staining. To further investigate the molecular mechanism by which the extract promoted apoptosis and inhibited the proliferation of the AML cells used, apoptotic protein expression was determined through western blots. Extract composition was elucidated by Gas Chromatography-Mass Spectrometry (GC-MS).

Results: Our results showed that the treatment with A. cherimola ethanolic leaf extract exhibited an inhibitory effect on the proliferation of both cancer cell lines used in a dose- and time-dependent manner, with no toxic effects on normal mononuclear cells (MNCs) isolated from human bone marrow. This effect was mediated by DNA fragmentation and apoptosis, as revealed by Cell Death ELISA and dual Annexin V/PI staining. Western blot analysis revealed a Bax/Bcl2 dependent mechanism of apoptosis, as well as PARP cleavage, confirming the apoptotic results observed previously. These effects may be attributed to the presence of terpenes which constitute a large component of the leafy extract, as revealed via GC-MS.
\end{abstract}

Conclusion: All the data presented in our study show that the terpene-rich A. cherimola ethanolic leaf extract exhibits an anti-proliferative and pro-apoptotic effect on the AML cell lines used.

Keywords: Annona cherimola, Acute myeloid leukemia, Apoptosis, Cancer, Terpenes

\section{Background}

Plant-derived compounds have been extensively used in the pharmaceutical industry for the treatment of several human diseases [1-3]. According to the world health organization (WHO), traditional medicine constitutes more than $80 \%$ of the total world's population primary health care needs [4]. Various phytochemicals such as alkaloids, flavonoids, lactones, terpenoids as well as terpenes are known to be key immunomodulators

\footnotetext{
* Correspondence: sandra.rizk@lau.edu.lb

${ }^{+}$Carl Ammoury and Maria Younes contributed equally to this work. ${ }^{1}$ Department of Natural Sciences, Lebanese American University, Byblos, Lebanon

Full list of author information is available at the end of the article
}

specifically as effective anti-inflammatory and anticancer agents [5-8].

One family of plants that has extensive traditional use is the Annonaceae. Annona, which is a genus of flowering plants in this sugar apple family, includes approximately 166 species and is considered the second largest genus in this family. The origin of the generic name is anón, a Hispaniolan Taíno name for the fruit $[9,10]$.

Several Annona species were found to exhibit antiparasitic [11], anti-inflammatory [12], and anti-tumor effects. An extract from A. glabra, rich in two diterpenoids displayed a cytotoxic effect on liver cancer cell lines by up-regulating the $\mathrm{Bax}$ to $\mathrm{Bcl}-2$ expression ratio [13] and on human leukemia cell lines in vitro [14]. A. squamosa

(c) The Author(s). 2019 Open Access This article is distributed under the terms of the Creative Commons Attribution 4.0 International License (http://creativecommons.org/licenses/by/4.0/), which permits unrestricted use, distribution, and reproduction in any medium, provided you give appropriate credit to the original author(s) and the source, provide a link to the Creative Commons license, and indicate if changes were made. The Creative Commons Public Domain Dedication waiver (http://creativecommons.org/publicdomain/zero/1.0/) applies to the data made available in this article, unless otherwise stated. 
chloroform seed extract also showed antitumor and proapoptotic effects on murine and human tumor cells through the induction of Reactive Oxygen Species (ROS) [15]. A. muricata ethyl acetate leaf extract exhibited a mitochondrial-mediated apoptosis on colon cancer cell lines [16] in vitro, on pancreatic cancer cells [17] in vitro and in vivo, and on breast cancer cell lines $[18,19]$ by upregulating Bax, p53 and downregulating Bcl-2 proteins. In addition, ethanolic and aqueous extracts from leaves, twigs and roots of $A$. muricata showed a strong anti-proliferative potential and pro-apoptotic effect through G0/G1 cycle arrest [20, 21].

A. cherimola, an edible subtropical fruit-bearing species is an evergreen low branched spreading tree [22] that belongs to the Annonaceae family and is commercially cultivated for its edible fruits and traditional uses [23]. Cherimoya, the large green fruit of the tree [24] has an exceptional taste and is reported to have been used as an antioxidant $[25,26]$ and in phytotherapy for the treatment of several ailments such as stomachache, pancreatic ulcers, skin disease [22, 24]. The various phytochemicals present in $A$. cherimola such as flavonoids, tannins, alkaloids, phytosterols, and terpenoids are traditionally utilized in the treatment of diabetes, nervous disorders and even cancer [25, 27]. Furthermore, annomolin and acetogenins, isolated from $A$. cherimola seed extracts [28], demonstrated a cytotoxic and proapoptotic effect in human prostate [29], breast [30], and colon [30] cancer cell lines. Moreover, A. cherimola leaves are sold and consumed by people to improve their health, such as in the treatment of hypercholesterolemia in Azores [31]. Other studies on ethanolic leaf extracts revealed an antitumor activity in human larynx epidermoid carcinoma cells in vitro [32].

The current study aims to explore the anti-cancer and anti-proliferative effects of a terpene-rich $A$. cherimola ethanolic leaf extract on acute myeloid leukemia cell lines in vitro.

\section{Methods}

Isolation and culture of normal mononuclear cells from human bone marrow

Normal mononuclear cells (MNCs)were offered by Prof. Marwan El-Sabban's Lab at the American university of Beirut (AUB) as a kind gift. The MNCs were obtained originally from bone marrow (BM) aspirate leftovers of healthy patients attending AUB Medical center (AUBMC). BM aspirates were centrifuged on Ficoll/Hypaque (GE Healthcare Life Sciences, Uppsala, Sweden), a density gradient step to separate MNCs from red blood cells and neutrophils. Then the buffy coat, which is the fraction of the anticoagulated blood containing most of the white blood cells, was aspirated and seeded in petri dishes using Dulbecco's Modified Eagle's Medium
(DMEM)-low glucose (Sigma, D6046) supplemented with 10\% FBS (FBS GibcoTM) and antibiotics (100 U/ $\mathrm{mL}$ penicillin and $100 \mu \mathrm{g} / \mathrm{mL}$ streptomycin, Lonza) in a humidified incubator at $37{ }^{\circ} \mathrm{C}$ and $5 \% \mathrm{CO}_{2}$. One week later, the cells in suspension were collected as a purified MNCs population and cultured in the same conditions mentioned formerly [33]. DMEM-low glucose complete medium was used in performing cytotoxicity assays on MNCs.

\section{Cell culture}

Two Acute Myeloid Leukemia (AML) cell lines were obtained from American Type Culture Collection: Monomac-1, established from the peripheral blood of a 64-year old AML patient, and KG-1, established from a 59-year old Caucasian male patient. The cells were cultured in RPMI-1640 Sigma-Aldrich (Roswell Park Memorial Institute) media supplemented with $10 \%$ fetal bovine serum (FBS Gibco $\left.{ }^{\mathrm{Tn}}\right)$ and antibiotics $(100 \mu \mathrm{g} / \mathrm{mL}$ of streptomycin, and $100 \mathrm{U} / \mathrm{mL}$ of penicillin from PenStrep Lonza) in a humidified atmosphere containing 5\% $\mathrm{CO}_{2}$ at $37^{\circ} \mathrm{C}$, and split as previously mentioned by Hodroj et al. [34]

\section{Plant material}

Annona cherimola leaves were collected from a tree in Awkar-Lebanon (90 m Above Sea Level), in January 2018, and identified by Dr. Nisrine Machaka-Houri. A voucher specimen was deposited in Beirut Arab University Herbarium (RCED2019-362).

\section{Preparation of crude leaf extract}

Leaves $(91.3 \mathrm{~g})$ were grinded, shaken and the extract was then prepared as previously described by Haykal et al [35]. The crude extract was weighed then dissolved in Dimethyl sulfoxide (DMSO) and diluted with RPMI to a final concentration of $8650 \mu \mathrm{g} / \mathrm{ml}$ at 5\% DMSO. The stock solution was diluted when needed with RPMI to be applied on cells. DMSO level maximally reached was $0.4 \%$ at $692 \mu \mathrm{g} / \mathrm{ml}$.

\section{Cell viability assay}

Wells were prepared and treated in triplicates with increasing concentrations $(173 \mu \mathrm{g} / \mathrm{mL}, 346 \mu \mathrm{g} / \mathrm{mL}, 519 \mu \mathrm{g} /$ $\mathrm{mL}$ and $692 \mu \mathrm{g} / \mathrm{mL}$ ) of AELE with one interference well, for $24 \mathrm{~h}, 48 \mathrm{~h}$ or $72 \mathrm{~h}$. For this purpose, AML cells were counted and seeded in 96-well plates at a density of $3 \times$ $10^{5}$ cells $/ \mathrm{mL}$, and were incubated overnight before treatment. The effect of AELE was assayed at these different timeframes using the MTS cell viability reagent (Promega) according to the Manufacturer's instructions. Cell proliferation was assessed via spectrophotometry by recording the absorbance at a wavelength of $492 \mathrm{~nm}$, using Varioskan $^{\mathrm{Tw}}$ LUX multimode microplate reader to detect 
metabolically active cells. Percentage proliferation was calculated by dividing the absorbance of the treated cells with the average absorbance of the control untreated cells. $\mathrm{IC}_{50}$ values were calculated using GraphPad Prism 8.

\section{Apoptosis detection using cell death detection ELISA} Cells were seeded and incubated overnight at a density of $1 \times 10^{5}$ cells $/ \mathrm{ml}$ in 24-well plates. Triplicates of wells treated with two increasing concentrations of AELE for $24 \mathrm{~h}$, were prepared and then compared to untreated control cells. A positive control well, treated with $100 \mu \mathrm{M}$ of etoposide (Abcam), was also included. Cells were extracted and lysed with incubation buffer, using the Cell Death ELISA kit (Roche), before isolation of fragmented cytosolic DNA. The procedure was then completed as previously described by Ghanem et al. [36]

\section{Apoptosis quantification by Annexin/PI staining}

Cells were seeded and incubated overnight at a density of $1 \times 10^{5}$ cells $/ \mathrm{ml}$ in 24-well plates. After incubation for $24 \mathrm{~h}$ with increasing concentrations of AELE, samples were collected, centrifuged at $1500 \mathrm{rpm}$ and $4{ }^{\circ} \mathrm{C}$, resuspended in suspension buffer and stained with Annexin and Propidium Iodine (PI) (Annexin V-fluorescein isothiocyanate [FITC] Apoptosis Detection Kit, Abcam). Samples were immediately analyzed using Accuri C6 flow cytometer.

\section{Western blot}

Cells were seeded and incubated overnight at a density of $3 \times 10^{5}$ cells $/ \mathrm{ml}$ in 6 -well plates, followed by treatment with increasing concentrations of AELE for $24 \mathrm{~h}$. Total proteins were extracted, quantified, separated and transferred to polyvinylidene difluoride (PVDF) membranes, which were then blocked as previously stated by Abou Najem et al [37].

The membranes were incubated with primary antibodies anti- $\beta$-actin (Santa Cruz Biotechnology, Dallas, TX, USA), anti-Bax (Elabscience, Houston, TX, USA), anti-Bcl2 (Elabscience, Houston, TX, USA), and anticPARP (Abcam, Cambridge, UK), overnight in the fridge, with $2 \%$ skimmed dry milk in PBS with $0.05 \%$ Tween 20, at the manufacturer's recommended concentrations: $1 / 1000$ for anti-Bax, anti-Bcl2, anti-cPARP and $1 / 3000$ for anti-actin. After washing, the membranes were incubated with anti-mouse secondary antibody (Bio-Rad, Hercules, CA, USA) at the recommended concentration (2:5000) for $1 \mathrm{~h}$ at room temperature. Another wash was performed, before imaging using Clarity $^{\mathrm{mat}}$ Western ECL Substrate (Abcam, Cambridge, UK) on ChemiDoc machine (BioRad, Hercules, CA, USA). The ImageJ computer program was used to quantify the blot bands, in order to calculate the relative expression of proteins [37].

\section{Gas chromatography - mass spectrometry}

AELE was analyzed via GC-MS as detailed earlier [35], and the peaks were identified from the literature (NIST11 and Wiley9).

\section{Statistical analysis}

All the experiments were carried out in triplicate and each experiment was repeated three times. The error bars are reported as mean \pm SEM. Statistical analysis and $p$-values were calculated by $\mathrm{t}$-tests or two-way ANOVA depending on the experiment. Significant differences were reported with * indicating a p-value: $0.01<p<0.05$, $*$ indicating a p-value: $0.001<p<0.01$, *** indicating a p-value: $0.0001<p<0.001$ and ${ }^{* * * * * *}$ indicating a p-value: $p<0.0001$.

\section{Results}

The effect of $A$. cherimola ethanolic leaf extracts on cell proliferation

The effect of AELE on Monomac-1 and KG-1 cells was quantified using the cell viability reagent MTS (Promega) via spectrophotometry. The viability was significantly reduced to less than $50 \%$ at higher doses. Treatment for longer time had a higher inhibitory effect. The extract exhibited anti-proliferative effects on the two AML cell lines in a dose and time-dependent manner, with a half-maximal inhibitory concentration $\left(\mathrm{IC}_{50}\right)$ of $333.4 \mu \mathrm{g} / \mathrm{mL}, \quad 254.1 \mu \mathrm{g} / \mathrm{mL}$ and $168 \mu \mathrm{g} / \mathrm{mL}$ for Monomac-1 (Fig. 1a), $254.5 \mu \mathrm{g} / \mathrm{mL}, \quad 34.8 \mu \mathrm{g} / \mathrm{mL}$ and $31.9 \mu \mathrm{g} / \mathrm{mL}$ for KG-1 (Fig. 1b), at 24, 48, and $72 \mathrm{~h}$ postAELE treatment, respectively. The maximum concentration of treatment used $(692 \mu \mathrm{g} / \mathrm{ml})$, exhibited a percentage proliferation of 23.87, 25.37 and $9.10 \%$ for Monomac-1 cells, and 25.39, 19.82 and $15.07 \%$ for KG-1 cells, at 24,48 and $72 \mathrm{~h}$ after treatment, respectively. AELE showed no inhibitory effect on the viability of normal MNCs from human BM (Fig. 2). This indicated that AELE exhibited selective anti-proliferative effects on all AML cell lines used, which was specific to AML cells, with no toxic effects on normal MNCs. All subsequent experiments were performed $24 \mathrm{~h}$ after treating the cells with AELE, in order to elucidate the underlying cellular mechanisms being altered prior to cell death.

\section{The effect of $A$. cherimola ethanolic leaf extracts on the induction of apoptosis}

After determining the concentrations within which the $\mathrm{IC}_{50}$ falls, in Monomac-1 and KG-1 upon treatment with AELE for $24 \mathrm{~h}$, the effect of the extract on induction of apoptosis was quantitatively assessed using Cell Death detection ELISA. In this technique, the enrichment 

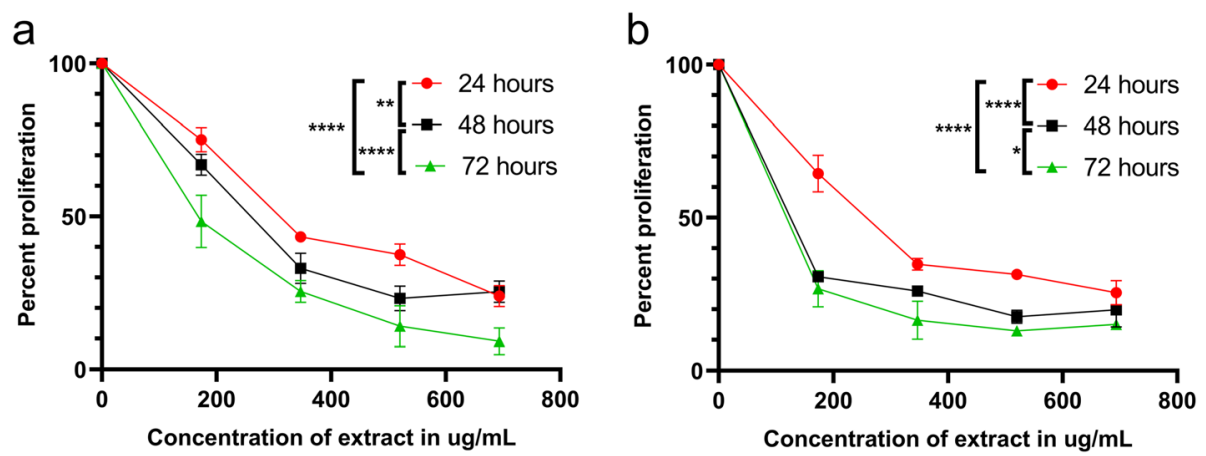

Fig. 1 The effect of AELE on cell proliferation using MTS assay. Proliferation of Monomac-1(a) and KG-1 (b) cells after 24, 48, and 72 h of treatment with increasing concentrations of AELE. The absorbance was measured at $492 \mathrm{~nm}$. A significant dose and time-dependent decrease in proliferation of AML cells was observed upon increasing concentrations of AELE. The IC50 s were reached at $333.4 \mu \mathrm{g} / \mathrm{mL}$ for Monomac-1 and $254.5 \mu \mathrm{g} / \mathrm{mL}$ for KG-1 at $24 \mathrm{~h}$. A time-dependent decrease in the $I_{50} \mathrm{~s}$ was observed for both cell lines at 48 and $72 \mathrm{~h}$. $\left(^{*}\right.$ indicates a $p$-value: $0.01<p<0.05{ }^{* *}$ indicates a $p$ - value: $0.001<p<0.01$, and ${ }^{* * *}$ indicates a $p$-value: $p<0.0001$ )

factor was the ratio of the absorbance measured for each drug to that of the untreated controls. The absorbance reflected the quantity of anti-DNA peroxidase, which in turn reflected the level of DNA fragmentation generated by apoptosis. The treatment showed an increase in the enrichment factors at $24 \mathrm{~h}$, which significantly rose from 1.25 to 2.22 for Monomac-1 (Fig. 3a), and from 3.26 to 6.57 for KG-1 (Fig. 3b), at 173 and $346 \mu \mathrm{g} / \mathrm{ml}$, respectively. These results revealed the ability of the extract to induce apoptosis in Monomac-1 and KG-1 in a dosedependent manner $(p<0.001)$.

Dual Annexin V/PI staining was used to quantitatively assess apoptosis induction upon various concentrations of AELE treatment. This approach can further determine whether cell death was via apoptotic or necrotic pathways. Cells that stained negative for both Annexin VFITC and PI (lower left quadrant), were considered normal living cells. Early apoptotic cells were Annexin V-

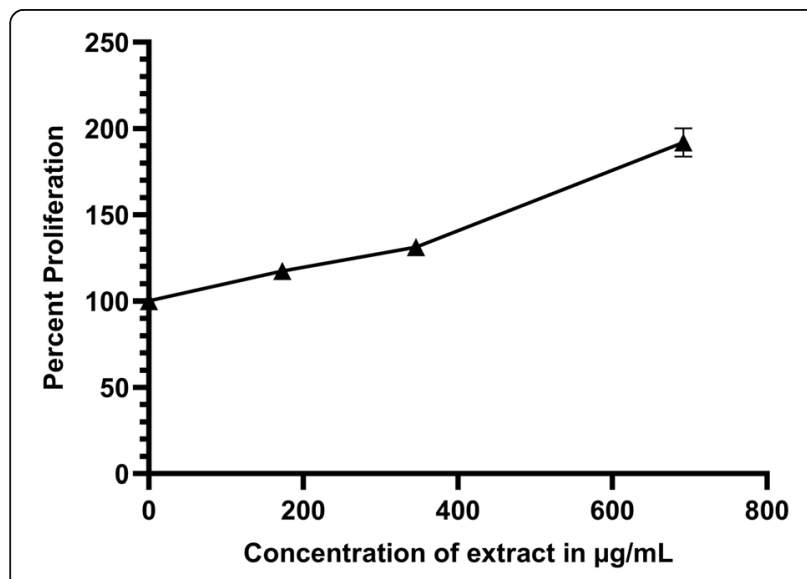

Fig. 2 The effect of AELE on MNCs isolated from Human Bone Marrow. AELE showed no inhibitory effect on Mononuclear Cells (MNCs) isolated from Human Bone Marrow
FITC positive and PI negative (lower right quadrant), whereas late apoptotic cells stained positive for both Annexin V-FITC and PI (upper right quadrant). Necrotic cells, on the other hand, exhibit positive staining to PI but negative staining to Annexin V-FITC (upper left quadrant). At $24 \mathrm{~h}$, the percentage of early apoptotic cells increased gradually from $2.5 \%$ in untreated Monomac-1 cells to 21.8 and $37.9 \%$ at 173 and $346 \mu \mathrm{g} /$ $\mathrm{ml}$, respectively (before and after the $\mathrm{IC}_{50}$ ) (Fig. 4a).

A similar pattern to the one seen in Monomac-1 cells was observed in KG-1 cells whereby the percentage of early apoptotic cells at $24 \mathrm{~h}$ reached 26 and $30.1 \%$ at 173 and $346 \mu \mathrm{g} / \mathrm{ml}$, respectively, compared to the control (10.5\%) (Fig. 4b). These results indicated that AELE induced apoptosis in Monomac-1 and KG-1 cells.

\section{The effect of $A$. cherimola ethanolic leaf extracts on the pro-apoptotic and anti-proliferative pathways}

Since AELE exhibited similar pro-apoptotic effects on both cell lines used, we then focused on Monomac-1 cells to identify the pathway by which AELE promoted apoptosis; the expression of certain proteins related to different pathways was determined using western blot analysis. The cells were treated for $24 \mathrm{~h}$ at concentrations closest to the half-maximal inhibitory concentration $\mathrm{IC}_{50}(173 \mu \mathrm{g} / \mathrm{ml}$ and $346 \mu \mathrm{g} / \mathrm{ml})$. Beta-actin was used as a housekeeping protein. The pro-apoptotic effect of $A$. cherimola was assessed by measuring the expression of cleaved poly (ADP-ribose) polymerase (PARP), Bax and Bcl-2. Cleaved PARP showed a significant upregulation upon the treatment with increasing concentrations. Moreover, the increase in the $\mathrm{Bax}$ to $\mathrm{Bcl} 2$ ratio revealed that the pathway by which cells were undergoing apoptosis was $\mathrm{Bax} / \mathrm{Bcl}-2$ dependent. These results confirm that apoptosis is triggered upon increasing doses of AELE (Fig. 5). 

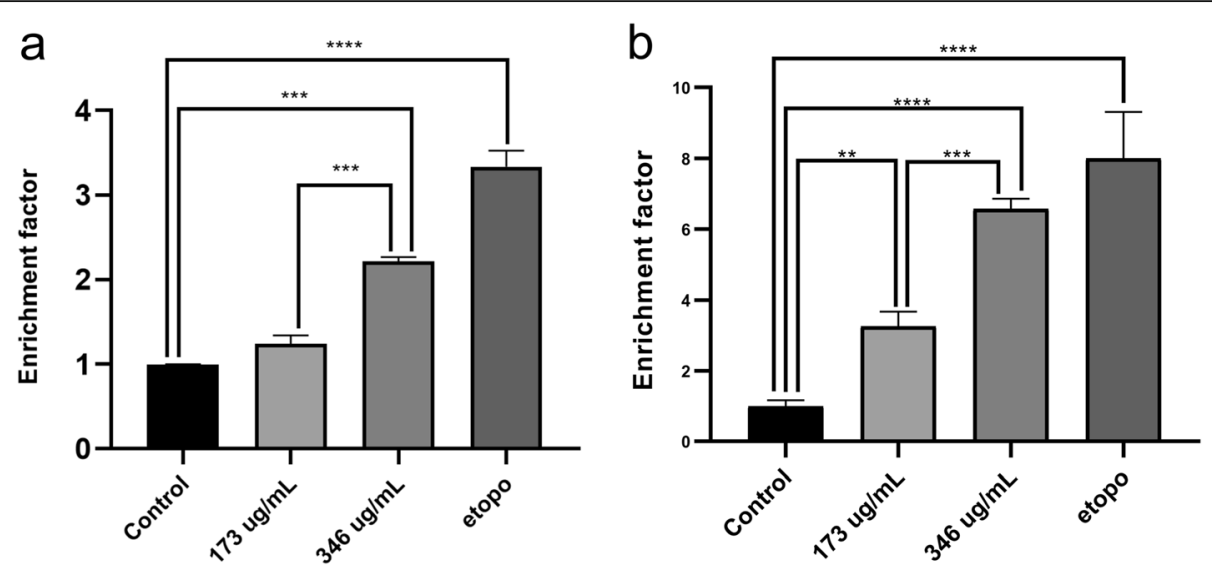

Fig. 3 The quantitative effect of AELE on induction of apoptosis using Cell Death ELISA. Cell Death ELISA on Monomac-1 (a) and KG-1 (b) cells, treated with the two concentrations of AELE closest to the IC50 (173 and $346 \mu \mathrm{g} / \mathrm{mL})$, as well as a positive control treated with etoposide for 24 h. A significant dose-dependent increase in enrichment factor is noted for AML cells upon treatment with two increasing doses of AELE for $24 \mathrm{~h}$. ${ }^{* *}$ indicates a $p$-value: $0.001<p<0.01{ }^{* * *}$ indicates a $p$-value: $0.0001<p<0.001$ and ${ }^{* * *}$ indicates a $p$ - value: $p<0.0001$ )

\section{Extract composition elucidation by GC-MS}

Gas Chromatography coupled to Mass Spectrometry was performed in order to determine the composition of the extract. The major identified compound was Terpenolene (Retention time $8.8155 \mathrm{~min}$ ), with an abundance of $16.0619 \%$. The second most abundant detected compound was Germacrene D (Retention time $11.4103 \mathrm{~min}$ ) with an abundance of $15.2476 \%$, followed by AlphaTocopherol (Retention times 59.5517 and $62.5523 \mathrm{~min}$ ), constituting $15.0038 \%$ of the extract. Beta-Sitosterol
(Retention time $61.2206 \mathrm{~min}$ ), was detected with an abundance of $7.0235 \%$. Some other unidentified compounds were detected at retention times 9.69, 10.1644, $10.4387,13.2736,13.4107$, and 15.6969 min constituting $5.7268,3.6257,1.7911,1.461,1.4701$ and $2.2314 \%$ of the extract, respectively (Fig. 6, Table 1).

\section{Discussion}

A correlation between diet and cancer prevention has been demonstrated by the implementation of many plant
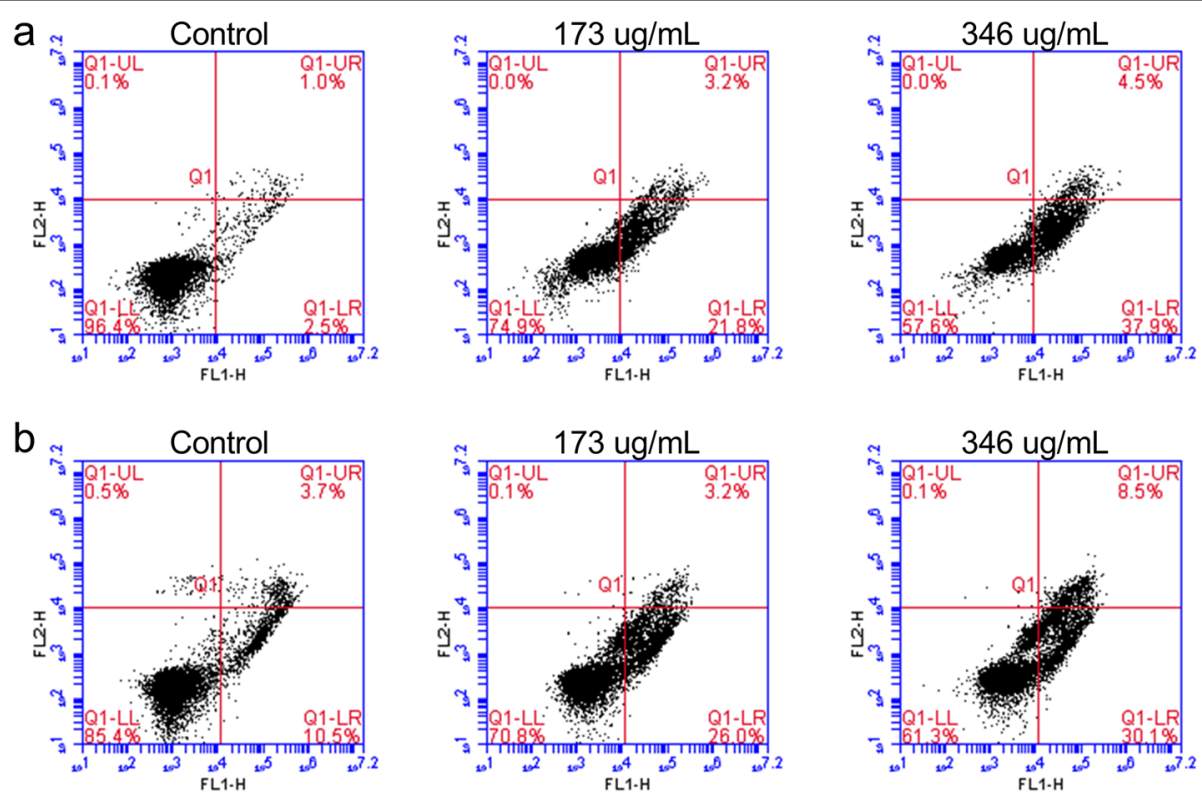

Fig. 4 The quantitative assessment of apoptosis induced by AELE using Annexin V/PI. Monomac-1 (a) and KG-1 (b) were treated with the two concentrations of AELE within which the IC50 falls (173 and $346 \mu \mathrm{g} / \mathrm{mL}$ ), followed by staining with Annexin V/PI, and analysis using flow cytometry. A shift from double-negative staining, to Annexin V-positive and PI-negative staining, an early apoptotic marker, upon treatment with AELE was observed. A slight increase in double positive stained cells was also observed 


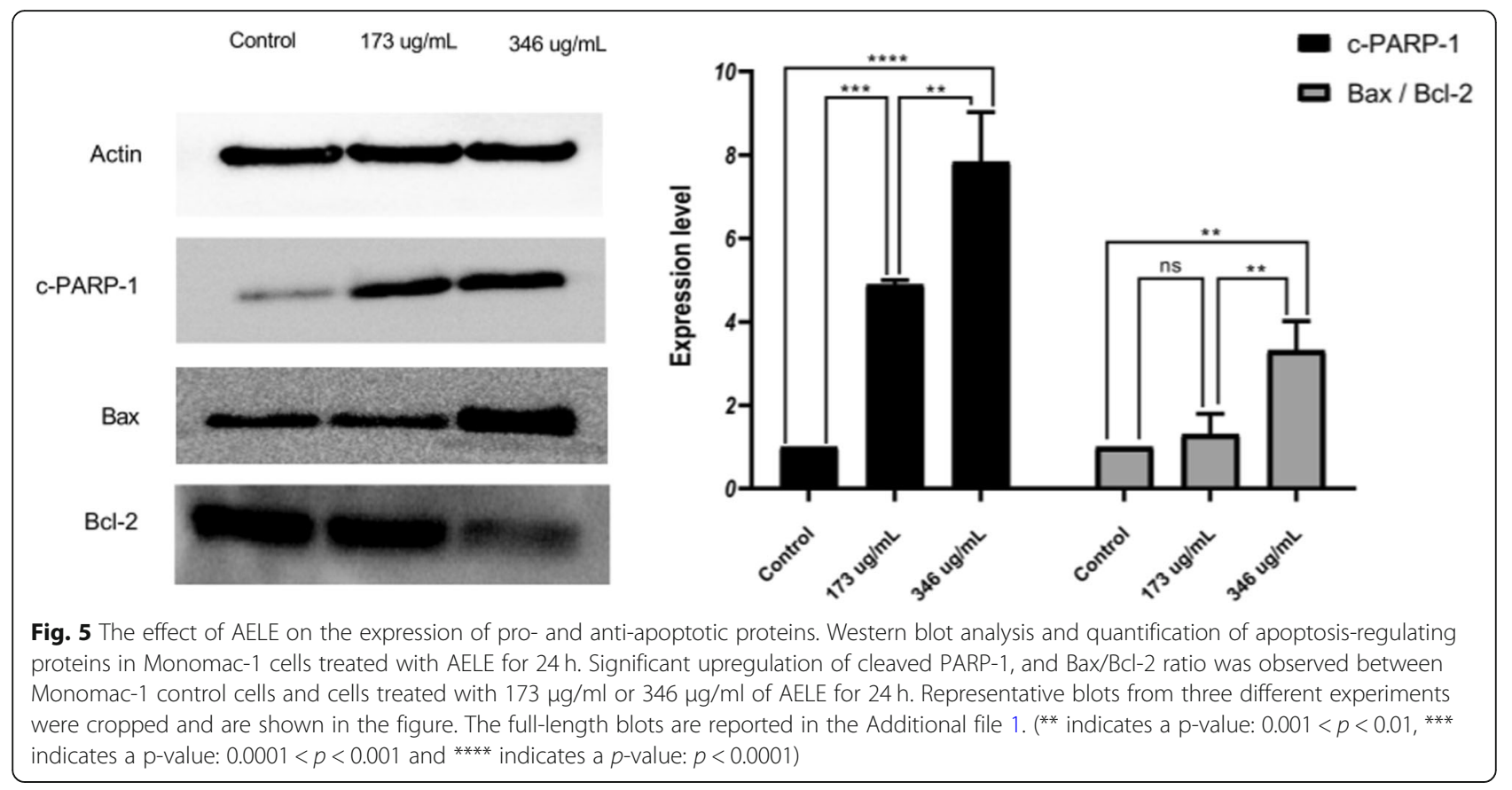

extracts which exhibited anti-cancerous effects as part of the human diet [10]. Many species classified under the Annona genus have shown antitumor effects against several types of cancers, including cervical, breast, prostate, lung, leukemia, colorectal, renal, pancreatic cancers [38]. Many studies have focused on the anti-proliferative effects of Annona muricata [16, 18, 20, 21], and Annona squamosa [39]. Moreover, most research conducted on Annona cherimola leaves has focused on its antihyperglycemic [40], and antiprotozoal activity [41], with few studies conducted to assess its antiproliferative activity. A recent study performed in our laboratory has reported the anti-proliferative effects of $A$. cherimola seed extract via activation of both intrinsic and extrinsic pro-apoptotic pathways in AML cells [35].
The aim of this study was to investigate the mechanism of action of AELE in the apoptotic pathways of the AML cell lines used (Monomac-1 and KG-1), whereby the results suggested a dose- and time-dependent antiproliferative effect within the $24 \mathrm{~h}$ treatment, with an $\mathrm{IC}_{50}$ of $333.4 \mu \mathrm{g} / \mathrm{mL}$ and $254.5 \mu \mathrm{g} / \mathrm{mL}$ for Monomac-1 and KG-1, respectively, as well as within the $48 \mathrm{~h}$ and $72 \mathrm{~h}$ treatment, with a significant time-dependent decrease in the $\mathrm{IC}_{50}$ value, and no inhibitory effect on normal MNCs from human BM. Interestingly, AELE exhibited positive effects on the proliferation of normal cells, similar to what has been reported in the literature for other anti-carcinogenic plant extracts such as Angelica sinensis [42].

According to Najmuddin et al., crude leaf extracts from Annona muricata Linn exhibited anti-cancer effects on breast cancer cell lines, with $\mathrm{IC}_{50}$ values at $72 \mathrm{~h}$

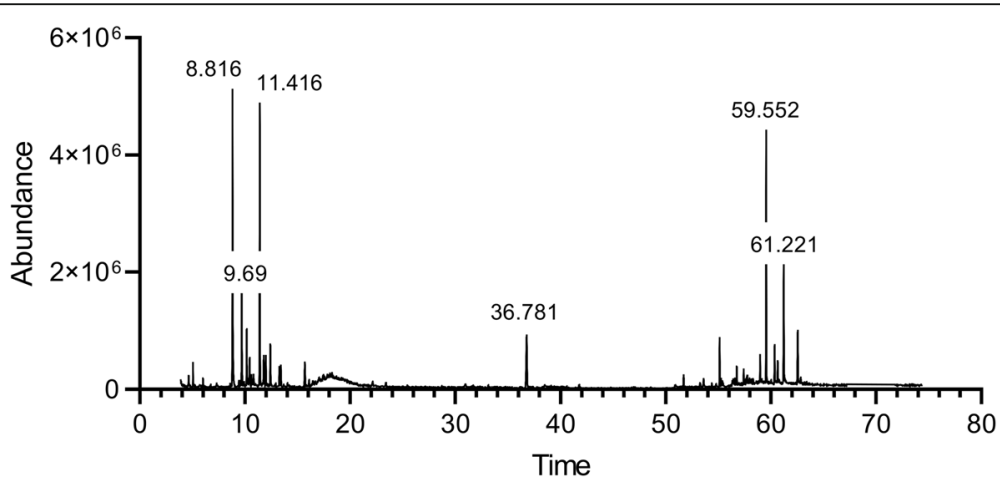

Fig. 6 Extract composition elucidation by GC-MS analysis 
Table 1 The composition of the A. cherimola ethanolic leaf extract as elucidated by GC-MS. The major detected compounds were Terpinolene (16.0619\%.), Germacrene D (15.2476\%), and Alpha-Tocopherol (15.0038\%). Other compounds remain unidentified

\begin{tabular}{llll}
\hline Peak & RT & Compound & \% Extract \\
\hline 1 & 8.8155 & Terpinolene & 16.0619 \\
2 & 9.69 & Unidentified A & 5.7268 \\
3 & 10.1644 & Unidentified B & 3.6257 \\
4 & 10.4387 & Unidentified C & 1.7911 \\
5 & 11.4103 & Germacrene D & 15.2476 \\
6 & 11.7876 & Gamma-Elemene & 1.7086 \\
7 & 11.9819 & Unidentified D & 1.4296 \\
8 & 12.4163 & $1,3-$ Cyclopentadiene, 1,2,3,4,5-pentamethyl- & 2.725 \\
9 & 13.2736 & Unidentified E & 1.461 \\
10 & 13.4107 & Unidentified F & 1.4701 \\
11 & 15.6969 & Unidentified G & 2.2314 \\
12 & 36.7813 & Phytol & 5.9387 \\
13 & 55.1279 & $(-)$-1,2,3,4-Tetrahydroisoquinoline, 6,7-dimethoxy-2-methyl-1-phenylmethanol & \\
14 & 58.9744 & Beta-Tocopherol & 2.8388 \\
15 & 59.5517 & Alpha-Tocopherol & 1.0881 \\
16 & 60.3576 & Campesterol & 11.1711 \\
17 & 60.6491 & Stigmasterol & 2.664 \\
18 & 61.2206 & Beta-Sitosterol & 1.3146 \\
\hline 19 & 62.5523 & Alpha-Tocopherol & 7.0235 \\
\hline
\end{tabular}

post-treatment, comparable to the ones reported in this study at $24 \mathrm{~h}$ post-AELE treatment, thus suggesting the effectiveness of AELE [18].

All experiments showed that AELE exhibited a dosedependent increase in apoptosis in the two AML cell lines used. These findings were supported by an increase in DNA fragmentation, as well as the double positive Annexin V/PI staining, indicating the translocation of phosphatidylserine moieties to the outer surface of cell membrane which is a hallmark of apoptosis.

After assessing the anti-proliferative and pro-apoptotic effects of AELE, we moved to decipher the underlying molecular mechanism by which apoptosis was triggered. The results obtained revealed that AELE induces apoptosis through a $\mathrm{Bax} / \mathrm{Bcl} 2$ dependent mechanism, in concordance with previous studies performed on Annona muricata leaves. Dinardo et al. suggested the effectiveness of a selective Bcl2-inhibitor, venetoclax in treating relapsed and refractory AML patients [43]. On the other hand, Reyna et al. developed a pharmacologically optimized Bax activator called BTSA1, which suppressed human AML xenografts, overcoming apoptosis resistance, thus suggesting that direct Bax activation is a possible treatment strategy in AML [44]. Movement of Bax from the cytosol to the mitochondria, through the Bax pores at the mitochondrial membrane, is critical in triggering DNA damage-mediated apoptosis $[45,46]$, which was observed through the dose-dependent increase in DNA fragmentation detected in cell death Elisa. Hence, upregulation of the pro-apoptotic protein Bax detected at $346 \mu \mathrm{g} / \mathrm{ml}$ (at $24 \mathrm{~h}$ ), accompanied by the downregulation of the anti-apoptotic protein $\mathrm{Bcl} 2$, is critical in disrupting the mitochondrial membrane potential, a hallmark of apoptosis. The effect of adding $\mathrm{Bax} / \mathrm{Bcl} 2$ inhibitors was not further explored since the efficacy of available inhibitors is still controversial [47].

Furthermore, the routine repair of DNA damage is normally controlled by PARP, which adds poly (ADP ribose) polymers in response to a variety of cellular stresses [48]. The increase in PARP cleavage, that was observed upon AELE treatment, will lead to its inactivation, coinciding with its inability to repair DNA damage. This is in line with the dose-dependent increase in DNA fragmentation observed in Cell Death ELISA, further confirming that the cytotoxicity of AELE is indeed apoptosis-triggered.

Upon analysis of the composition of the extract, Terpinolene was found to be the major compound. Terpinolene is one of the most abundant monoterpenes, which is known for its sedative [8], antifungal [49], anticancer, antioxidant [6], apoptotic [50] activities, as well antiinflammatory and anti-nociceptive activities in association with diclofenac [7]. Interestingly, terpinolene, which is a main constituent of the essential oil of 
Protium heptaphyllum, exhibited an anti-mutagenic activity, suggesting its potential use as a chemo-preventive agent for cancer [51]. $\alpha$-Pinene, another bicyclic monoterpene, was also found to induce cell cycle arrest in mice Xenograft models, and promote apoptosis in human prostate cancer [52].

The second most common compound in the extract was the sesquiterpene Germacrene D. This compound was previously identified by Bomfim et al., who reported the presence of various sesquiterpenes in the essential oil extracted from Annona vepretorum leaves. This extract exhibited in vitro antitumor effects in B16-F10 (mouse melanoma), HL-60 (human promyelocytic leukemia), K562 (human CML), and HepG2 (human hepatocellular carcinoma) cells, as well as in vivo activity [53]. According to Shakeri et al., germacrene D was also found to be the most abundant component in Nepeta ucrainica L. spp. kopetdaghensis, which was found to be cytotoxic in human ovarian carcinoma A2780 and human breast adenocarcinoma MCF-1 cell lines in vitro [54]. Furthermore, terpenes are the second most common abundant components of Decatropis bicolor leaf extracts, which triggered apoptosis in MDA-MB-231 breast cancer cell line, through a $\mathrm{Bax} / \mathrm{Bcl} 2$ dependent mechanism, translated by a dose-dependent upregulation of Bax, and downregulation of Bcl2 [55], similar to what was observed in our study.

A third major component in AELE was Alphatocopherol, an isoform of vitamin E. Zulkapli et al. demonstrated its antitumor activity in oral squamous carcinoma cells ORL-48, whereby accumulation of cells at the sub-G0 phase, along with cell shrinkage and apoptotic bodies were reported [56].

Another identified compound in AELE was $\beta$ sitosterol. A study by Zhao et al. reported its ability to inhibit cell growth and trigger apoptosis in SGC-7901 human stomach cancer cells in vitro, in a $\mathrm{Bax} / \mathrm{Bcl} 2$ and caspase dependent manner [57]. Similar findings were observed on U937 AML cells, involving caspase 3 activation, and an increase in the $\mathrm{Bax} / \mathrm{Bcl} 2$ ratio [58]. Other studies suggest the anti-inflammatory capacity of $\beta$ sitosterol [59], as well as its antihyperglycemic and insulin-releasing activities [60]. Other compounds in AELE remain unidentified and require further investigation. A study performed by Díaz-de-Cerio E. et al reports the presence of polar compounds in Annona cherimola leaves using a combined approach of MS and NMR techniques, as well as amino acids, carbohydrates, organic acids, phenolic acids and derivatives, cholines, flavonoids and phenylpropanoids [61].

\section{Conclusions}

In conclusion, Annona cherimola ethanolic leaf extracts showed a clear pro-apoptotic effect on Acute Myeloid
Leukemia cell lines in vitro. The apoptotic activity of this compound was confirmed through the upregulation of Bax, downregulation of $\mathrm{Bcl} 2$, and cleavage of PARP. Chemical analysis of the extract showed that it is also rich in terpenes in addition to other compounds with antioxidant, sedative, anti-inflammatory and antibacterial properties. Further investigations are required to study the effects of the unidentified compounds in the extract, and to confirm the anti-tumor effect of the extract in vivo.

\section{Additional file}

Additional file $\mathbf{1}$ The proapoptotic effect of a Terpene-Rich annona cherimola leaf extract on leukemic cell lines.

\section{Abbreviations}

AELE: Annona cherimola ethanolic leaf extract; AML: Acute Myeloid Leukemia; ANOVA: Analysis of Variance; BM: Bone Marrow; DMEM: Dulbecco's Modified Eagle Medium; DMSO: Dimethyl Sulfoxide; FBS: Fetal Bovine Serum; GCMS: Gas Chromatography-Mass Spectrometry; IC50: Half-maximal inhibitory concentration; MNC: Mononuclear Cells; PARP: Poly (ADP-ribose) polymerase; PI: Propidium lodine; PVDF: Polyvinylidene Difluoride; ROS: Reactive Oxygen Species; RPMI: Roswell Park Memorial Institute; SDS-PAGE: Sodium dodecyl sulfate-Polyacrylamide Gel Electrophoresis; SEM: Standard Error of the mean; WHO: World Health Organization

\section{Acknowledgments}

The authors acknowledge Dr. Nisrine Machaka-Houri for identifying the plant being studied.

\section{Authors' contributions}

CA and MY, performed experiments, interpreted the results of KG-1 and Monomac-1cells and wrote the first version of the manuscript. ME performed some of the western blots. MS and RS collected the seeds, optimized the conditions for extraction and edited the manuscript. RT and TH performed the chemical characterization of the extract. MH and PN did the flow cytometry analysis. RK optimized the western blots and edited the manuscript. SR developed the concept of the study, interpreted the results and generated the final version of the manuscript. All authors have read and approved the manuscript.

\section{Funding}

This study was financially funded by intramural funds from the School Research Development Council (SRDC-School of Arts and Sciences, Lebanese American University) and by the Department of Natural Sciences (Lebanese American University) to secure space, equipment, reagents and chemicals.

\section{Availability of data and materials}

Data sharing is not applicable to this article as no datasets were generated or analyzed during the current study. The full length blots have been submitted as supplementary material.

Ethics approval and consent to participate

Not applicable since the manuscript does not involve human subjects.

\section{Consent for publication}

Not applicable since the manuscript does not involve human subjects.

\section{Competing interests}

The authors report no conflicts of interest in this work.

\section{Author details}

'Department of Natural Sciences, Lebanese American University, Byblos, Lebanon. ${ }^{2}$ Laboratory of Regenerative Hematopoiesis, Swiss Institute for Experimental Cancer Research (ISREC) \& Institute of Bioengineering (IBI), 
School of Life Sciences, Ecole Polytechnique Fédérale de Lausanne (EPFL), Lausanne, Switzerland. 'Biochemical Engineering Department, UCL, London, UK.

Received: 23 July 2019 Accepted: 22 November 2019 Published online: 12 December 2019

\section{References}

1. Dar RA, Shahnawaz M, Qazi PH. General overview of medicinal plants: A review. J Pharmacol. 2017;6(6):349-51.

2. Roy A, Ahuja S, Bharadvaja N. A Review on Medicinal Plants against Cancer; 2017. p. 5.

3. Ekor M. The growing use of herbal medicines: issues relating to adverse reactions and challenges in monitoring safety. Front Pharmacol. 2014; 10 [cited 2019 Mar 10];4. Available from: https://www.ncbi.nlm.nih.gov/pmc/ articles/PMC3887317/.

4. WHO Guidelines on Safety Monitoring of Herbal Medicines in Pharmacovigilance Systems [Internet]. [cited 2019 Mar 10]. Available from: http://apps.who.int/medicinedocs/en/m/abstract/Js7148e/

5. Jantan I, Ahmad W, Bukhari SNA. Plant-derived immunomodulators: an insight on their preclinical evaluation and clinical trials. Front Plant Sci [Internet]. 2015 Aug 25 [cited 2019 Mar 10];6. Available from: https://www. frontiersin.org/article/10.3389/fpls.2015.00655/full

6. Aydin E, Türkez H, Taşdemir S.. Anticancer and antioxidant properties of Terpinolene in rat brain cells. Arch Ind Hyg Toxicol. 2013 Sep 1;64(3):415-24.

7. Macedo EMA, Santos WC, Sousa Neto BP, Lopes EM, Piauilino CA, Cunha FVM, et al. Association of terpinolene and diclofenac presents antinociceptive and anti-inflammatory synergistic effects in a model of chronic inflammation. Braz J Med Biol Res. 2016;49(7) [cited 2019 Mar 6]. Available from: http://www.scielo.br/scielo.php?script=sci_arttext\&pid=S01 00-879X2016000700602\&lng=en\&tlng=en.

8. Ito $K$, Ito $M$. The sedative effect of inhaled terpinolene in mice and its structure-activity relationships. J Nat Med. 2013 Oct;67(4):833-7.

9. Tundis R, Xiao J, Loizzo MR. Annona species (Annonaceae): a rich source of potential antitumor agents?: antitumor Annona species. Ann N Y Acad Sci. 2017 Jun;1398(1):30-6.

10. Greenwald P, Clifford CK, Milner JA. Diet and cancer prevention. Eur J Cancer Oxf Engl 1990. 2001;37(8):948-65.

11. Santos Pimenta LP, Pinto GB, Takahashi JA. E Silva LGF, Boaventura MAD. Biological screening of Annonaceous Brazilian medicinal plants using Artemia salina (brine shrimp test). Phytomedicine. 2003;10(2-3):209-12.

12. Siebra CA, Nardin JM, Florão A, Rocha FH, Bastos DZ, Oliveira BH, et al. Potencial antiinflamatório de Annona glabra. Annonaceae Rev Bras Farmacogn. 2009:19(1a):82-8

13. Zhang $Y$, Peng $H$, Xia $G$, Wang $M$, Han $Y$. Anticancer effect of two diterpenoid compounds isolated from Annona glabra Linn. Acta Pharmacol Sin. 2004;1-6.

14. Cochrane CB, Nair PKR, Melnick SJ, Resek AP, Ramachandran C. Anticancer effects of Annona glabra plant extracts in human leukemia cell lines. Anticancer Res. 2008;28(2A):965-71.

15. Pardhasaradhi BW, Reddy M, Ali AM, Kumari AL, Khar A. Differential cytotoxic effects of Annona squamosa seed extracts on human tumour cell lines: role of reactive oxygen species and glutathione. J Biosci. 2005;30(2): 237-44

16. Moghadamtousi SZ, Kadir HA, Paydar M, Rouhollahi E, Karimian H. Annona muricata leaves induced apoptosis in A549 cells through mitochondrialmediated pathway and involvement of NF-kB. BMC Complement Altern Med. 2014; Dec [cited 2019 Mar 9];14(1). Available from: http:// bmccomplementalternmed.biomedcentral.com/articles/10.1186/1472-6 882-14-299

17. Torres MP, Rachagani S, Purohit V, Pandey P, Joshi S, Moore ED, et al. Graviola: a novel promising natural-derived drug that inhibits tumorigenicity and metastasis of pancreatic cancer cells in vitro and in vivo through altering cell metabolism. Cancer Lett. 2012:323(1):29-40.

18. SUF SN, Romli MF, Hamid M, Alitheen NB, NMA NAR. Anti-cancer effect of Annona muricata Linn Leaves Crude Extract (AMCE) on breast cancer cell line. BMC Complement Altern Med. 2016; Dec [cited 2019 Mar 9];16(1) Available from: http://bmccomplementalternmed.biomedcentral.com/ articles/10.1186/s12906-016-1290-y.

19. Kim JY, Dao TTP, Song K, Park SB, Jang H, Park MK, et al. Annona muricato leaf extract triggered intrinsic apoptotic pathway to attenuate cancerous features of triple negative breast Cancer MDA-MB-231 cells. Evid Based Complement Alternat Med. 2018;2018:1-10.

20. Pieme CA, Kumar SG, Dongmo MS, Moukette BM, Boyoum FF, Ngogang JY, et al. Antiproliferative activity and induction of apoptosis by Annona muricata (Annonaceae) extract on human cancer cells. BMC Complement Altern Med [Internet]. 2014 Dec [cited 2019 Mar 6];14(1). Available from: https://bmccomplementalternmed.biomedcentral.com/articles/10.1186/14 72-6882-14-516

21. Abdul Wahab SM, Jantan I, Haque MdA, Arshad L. Exploring the Leaves of Annona muricata L. as a Source of Potential Anti-inflammatory and Anticancer Agents. Front Pharmacol [Internet]. 201820 [cited 2019 Mar 6];9. Available from: https://www.ncbi.nlm.nih.gov/pmc/articles/PMC6019487/

22. Jamkhande PG, Ajgunde BR, Jadge DR. Annona cherimola mill. (custard apple): a review on its plant profile, nutritional values, traditional claims and ethnomedicinal properties. Orient Pharm Exp Med. 2017 Sep;17(3):189-201.

23. Jyothi A, Venkatesh K, Chakrapani P, Rani R. Phytochemical and Pharmacological potential of Annona cherimola-A Review, vol. 3; 2011. p. 439.

24. Albuquerque TG, Santos F, Sanches-Silva A, Beatriz Oliveira M, Bento AC, Costa HS. Nutritional and phytochemical composition of Annona cherimola mill. Fruits and by-products: potential health benefits. Food Chem. 2016;193: 187-95.

25. BENARBA Bachir, MENDAS Okba Ibnou Nafaa, Setti RIGHI. Phytochemical analysis, antioxidant and anti-Candida albicans activities of Annona cherimola Mill. fruit pulp. Zenodo [Internet]. 2018 Nov 23 [cited 2019 Mar 11]; Available from: https://zenodo.org/record/1495218

26. Gupta-Elera G, Garrett AR, Martinez A, Robison RA, O'Neill KL. The antioxidant properties of the cherimoya (Annona cherimola) fruit. Food Res Int. 2011;44(7):2205-9.

27. Loizzo MR, Tundis R, Bonesi M, Menichini F, Mastellone $V$, Avallone $L$, et al, Radical scavenging, antioxidant and metal chelating activities of Annona cherimola mill. (cherimoya) peel and pulp in relation to their total phenolic and total flavonoid contents. J Food Compos Anal. 2012;25(2):179-84.

28. Kim DH, Ma ES, Suk KD, Son JK, Lee JS, Woo MH. Annomolin and Annocherimolin, new cytotoxic Annonaceous Acetogenins from Annona cherimolia seeds. J Nat Prod. 2001:64(4):502-6.

29. Bode AM, Dong Z. Cancer prevention research — then and now. Nat Rev Cancer. 2009:9(7):508-16.

30. Newman DJ, Cragg GM. Natural products as sources of new drugs over the last 25 years $^{\perp}$. J Nat Prod. 2007;70(3):461-77.

31. Falé PL, Ferreira C, Maruzzella F, Helena Florêncio M, Frazão FN, Serralheiro MLM. Evaluation of cholesterol absorption and biosynthesis by decoctions of Annona cherimola leaves. J Ethnopharmacol. 2013;150(2):718-23.

32. Betancur-Galvis L, Saez J, Granados H, Salazar A, Ossa J. Antitumor and antiviral activity of Colombian medicinal plant extracts. Mem Inst Oswaldo Cruz. 1999;94(4):531-5

33. Zibara K, Hamdan R, Dib L, Sindet-Pedersen S, Kharfan-Dabaja M, Bazarbachi A, Covas DT, et al. Acellular Bone Marrow Extracts Significantly Enhance Engraftment Levels of Human Hematopoietic Stem Cells in Mouse XenoTransplantation Models. PLoS ONE. 2012;7(7):e40140.

34. Hodroj MH, Jardaly A, Abi Raad S, Zouein A, Rizk S. Andrographolide potentiates the antitumor effect of topotecan in acute myeloid leukemia cells through an intrinsic apoptotic pathway. Cancer Manag Res. 2018;10: 1079-88.

35. Haykal T, Nasr P, Hodroj MH, Taleb RI, Sarkis R, MNEl M, et al. Annona cherimola Seed Extract Activates Extrinsic and Intrinsic Apoptotic Pathways in Leukemic Cells. Toxins. 2019;11(9):506.

36. Ghanem Z, Mohamad H, Haykal AN, et al. The Vitamin E Derivative Gamma Tocotrienol Promotes Anti-Tumor Effects in Acute Myeloid Leukemia Cell Lines. Nutrients. 2019;11(11):2808.

37. Najem SA, Khawaja G, Hodroj MH, Rizk S. Synergistic effect of epigenetic inhibitors Decitabine and Suberoylanilide Hydroxamic acid on colorectal Cancer in vitro. Curr Mol Pharmacol. 2019;12(4):281-300.

38. Rady I, Bloch MB, Chamcheu R-CN, Banang Mbeumi S, Anwar MR Mohamed $\mathrm{H}$, et al. Anticancer properties of Graviola ( Annona muricata ): a comprehensive mechanistic review. Oxidative Med Cell Longev. 2018;2018: $1-39$.

39. Chen $Y$, Chen $Y$, Shi $Y, M a ~ C$, Wang $X, L i$ Y, et al. Antitumor activity of Annona squamosa seed oil. J Ethnopharmacol. 2016;193:362-7.

40. Calzada F, Solares-Pascasio J, Ordoñez-Razo R, Velazquez C, Barbosa E, García-Hernández N, et al. Antihyperglycemic activity of the leaves from 
Annona cherimola miller and rutin on alloxan-induced diabetic rats. Pharm Res. 2017:9(1):1.

41. Calzada F, Correa-Basurto J, Barbosa E, Mendez-Luna D, Yepez-Mulia L. Antiprotozoal constituents from Annona cherimola miller, a plant used in Mexican traditional medicine for the treatment of diarrhea and dysentery. Pharmacogn Mag. 2017 Mar;13(49):148-52.

42. Jiang X, Liu L, Zhang B, Lu Z, Qiao L, Feng X, et al. Effects of Angelica Extract on Schwann Cell Proliferation and Expressions of Related Proteins. Evid-Based Complement Altern Med ECAM. 2017; [cited 2019 Oct 1];2017. Available from: https://www.ncbi.nlm.nih.gov/pmc/articles/PMC5540469/.

43. DiNardo CD, Rausch CR, Benton C, Kadia T, Jain N, Pemmaraju N, et al. Clinical experience with the BCL2-inhibitor venetoclax in combination therapy for relapsed and refractory acute myeloid leukemia and related myeloid malignancies. Am J Hematol. 2018;93(3):401-7.

44. Reyna DE, Garner TP, Lopez A, Kopp F, Choudhary GS, Sridharan A, et al. Direct Activation of BAX by BTSA1 Overcomes Apoptosis Resistance in Acute Myeloid Leukemia. Cancer Cell. 2017;32(4):490-505.e10.

45. Kushnareva Y, Andreyev AY, Kuwana T, Newmeyer DD, Hardwick JM. Bax Activation Initiates the Assembly of a Multimeric Catalyst that Facilitates Bax Pore Formation in Mitochondrial Outer Membranes. PLoS Biol. 2012;10(9): e1001394.

46. Wang P, Wang P, Liu B, Zhao J, Pang Q, Agrawal SG, et al. Dynamin-related protein Drp1 is required for Bax translocation to mitochondria in response to irradiation-induced apoptosis. Oncotarget [Internet]. 2015 Sep 8 [cited 2019 Mar 12];6(26). Available from: http://www.oncotarget.com/fulltext/4200

47. Garner TP, Amgalan D, Reyna DE, Li S, Kitsis RN, Gavathiotis E. Smallmolecule allosteric inhibitors of BAX. Nat Chem Biol. 2019;15(4):322-30.

48. Chaitanya GV, Alexander JS, Babu PP. PARP-1 cleavage fragments: signatures of cell-death proteases in neurodegeneration. Cell Commun Signal CCS. 2010;8:31.

49. Sampietro D, Melina E, Belizana M, Terán Baptista Z, M AV, Catalan C. Essential Oils from Schinus Species of Northwest Argentina: Composition and Antifungal Activity, vol. 9; 2014. p. 1019

50. Agus HH, Sarp C, Cemiloglu M. Oxidative stress and mitochondrial impairment mediated apoptotic cell death induced by terpinolene in Schizosaccharomyces pombe. Toxicol Res. 2018;7(5):848-58.

51. de Lima E, Cazelli DP, Pinto F, Mazuco R, Kalil I, Lenz D, et al. Essential oil from the resin of Protium heptaphyllum: chemical composition, cytotoxicity, antimicrobial activity, and antimutagenicity. Pharmacogn Mag. 2016;12(45): 42.

52. Zhao Y, Chen R, Wang Y, Yang Y. a-Pinene inhibits human prostate Cancer growth in a mouse Xenograft model. Chemotherapy. 2018;63(1):1-7.

53. M Bomfim L, Menezes L, Carolina BC, Rodrigues A, Dias R, Gurgel C, Soares $M$, et al. Antitumour Activity of the Microencapsulation of Annona vepretorum Essential Oil, vol. 118; 2015

54. Shakeri A, Khakdan F, Soheili V, Sahebkar A, Rassam G, Asili J. Chemical composition, antibacterial activity, and cytotoxicity of essential oil from Nepeta ucrainica L. spp. kopetdaghensis. Ind Crop Prod. 2014;58:315-21.

55. Estanislao Gómez CC, Aquino Carreño A, Pérez Ishiwara DG, San Martín Martínez E, Morales López J, Pérez Hernández N, et al. Decatropis bicolor (Zucc.) Radlk essential oil induces apoptosis of the MDA-MB-231 breast cancer cell line. BMC Complement Altern Med [Internet]. 2016 Dec [cited 2019 Mar 6];16(1). Available from: http://bmccomplementalternmed. biomedcentral.com/articles/10.1186/s12906-016-1136-7

56. Zulkapli R, Abdul Razak F, Zain RB. Vitamin E (a-Tocopherol) exhibits antitumour activity on Oral squamous carcinoma cells ORL-48. Integr Cancer Ther. 2016;16(3):414-25.

57. Zhao Y, Chang SKC, Qu G, Li T, Cui H. ß-Sitosterol inhibits cell growth and induces apoptosis in SGC-7901 human stomach Cancer cells. J Agric Food Chem. 2009;57(12):5211-8

58. Park C, Moon D-O, Rhu C-H, Choi BT, Lee WH, Kim G-Y, et al. Leukemic U937 Cells through Activation of Caspase-3 and Induction of Bax/Bcl-2 Ratio. Biol Pharm Bull. 2007;30(7):7.

59. Paniagua-Pérez R, Flores-Mondragón G, Reyes-Legorreta C, Herrera-López B, Cervantes-Hernández I, Madrigal-Santillán O, et al. Evaluation of the antiinflammatory capacity of BETA-SITOSTEROL in rodent assays. Afr J Tradit Complement Altern Med. 2016;14(1):123-30.

60. Ivorra M, D'Ocon P, Paya M, Villar A. Antihyperglycemic and insulin-releasing effects of B-sitosterol 3-B-D-Glucoside and its aglycone, B-sitosterol, vol. 296; 1988. p. 224.
61. Díaz-de-Cerio E, Aguilera-Saez LM, Gómez-Caravaca AM, Verardo V, Fernández-Gutiérrez A, Fernández I, et al. Characterization of bioactive compounds of Annona cherimola L. leaves using a combined approach based on HPLC-ESI-TOF-MS and NMR. Anal Bioanal Chem. 2018;410(15): 3607-19.

\section{Publisher's Note}

Springer Nature remains neutral with regard to jurisdictional claims in published maps and institutional affiliations.
Ready to submit your research? Choose BMC and benefit from:

- fast, convenient online submission

- thorough peer review by experienced researchers in your field

- rapid publication on acceptance

- support for research data, including large and complex data types

- gold Open Access which fosters wider collaboration and increased citations

- maximum visibility for your research: over $100 \mathrm{M}$ website views per year

At $\mathrm{BMC}$, research is always in progress.

Learn more biomedcentral.com/submissions 